\title{
35. CRETACEOUS HOTSPOT TRACKS THROUGH THE MARSHALL ISLANDS ${ }^{1}$
}

\author{
Douglas D. Bergersen ${ }^{2}$
}

\begin{abstract}
Pacific Plate rotations show that the Marshall Islands were located near French Polynesia during the time of their construction in the Cretaceous. Edifices within the various island chains fail to show a simple linear age progression in the direction of plate motion. Mid-Cretaceous fossil ages and Late Cretaceous radiometric ages suggest that two episodes of volcanism and uplift have occurred across this region. The Cretaceous tracks of the Cook-Austral and Society island hotspots superimposed on oblique Mercator projections of the Marshall Islands topography show that (1) the Ralik Chain formed during the Late Cretaceous but not over any of the present French Polynesian hotspots, (2) the northern Marshall Islands crossed the Macdonald hotspot during the stage from 74 to $100 \mathrm{Ma}$, (3) the Ratak Chain formed over either the Rurutu or Society hotspots, and (4) the Anewetak-Ujlan volcanic cluster correlates with the Rarotonga hotspot and a change in plate motion. Misfits between the model tracks for the French Polynesian hotspots and the observed topography and sparse age information for the Marshall Islands may result from either (1) more Cretaceous hotspots in French Polynesia than are currently observed, (2) weaker mantle plumes and consequently a shorter duration of volcanism in the French Polynesia area, or (3) the slow movement of existing hotspots relative to other Pacific hotspots.
\end{abstract}

\section{INTRODUCTION}

The complicated history of volcanism across the Pacific Plate is well recorded by the numerous islands, atolls, guyots, seamounts, and mid-ocean plateaus occupying the western Pacific, including those composing the Marshall Islands. Regional uplift and large-scale fracturing of the plate were early hypotheses for explaining the preponderance of these volcanic features (Menard, 1964). Age and depth information from several legs of the Deep Sea Drilling Project (DSDP) and from dredging of seamounts throughout the Pacific basin confirmed that regional uplift and extensive volcanism occurred during the Cretaceous across an area extending from the Mid-Pacific Mountains and the Line Islands westward to the Marshall Islands and the Nauru Basin (e.g., Winterer, Ewing, et al., 1973; Larson, Moberly, et al., 1975; Schlanger, Jackson, et al., 1976; Larson, Schlanger et al., 1981; Moberly, Schlanger, et al., 1986). However, the duration of the volcanism as shown in the DSDP cores was still somewhat debatable. For example, after drilling at Site 462, Schlanger and Premoli Silva (1981) postulated that uplift and mid-plate volcanism began in Barremian to early Aptian time and continued through the Maastrichtian, whereas Moberly and Jenkyns (1981) argued for two distinct episodes of volcanism separated by approximately 40 m.y.

Additional dredging and drilling efforts over the past $5 \mathrm{yr}$ have resulted in a number of radiometric and fossil ages for the edifices composing the Marshall Islands. These ages suggest a history of uplift and volcanic overprinting of the original ocean floor, focused largely into two main volcanic chains (Fig. 1; Table 1). The easternmost line of volcanoes, the Ratak Chain, extends from around Limalok Guyot in the south to Woden-Kopakut Guyot in the north, whereas the more centrally located Ralik Chain extends from Jalwoj Atoll in the south to around Lewa Guyot in the north. A third geographic province formed by a cluster of volcanoes centered about Ujlan and Anewetak atolls lies farther to the west.

Edifices within these three provinces fail to show a simple, linear age progression in the direction of plate motion, in contrast with many other hotspot chains in the Pacific (e.g., the Hawaiian Islands, the Emperor Seamounts, and the Society Islands). Davis et al. (1989) and Pringle (1992) have shown that younger edifices lie "downstream" from older edifices in both the Ratak and Ralik chains (Fig. 1 and Table

'Haggerty, J.A., Premoli Silva, I., Rack, F., and McNutt, M.K. (Eds.), 1995. Proc. ODP. Sci. Results, 144: College Station, TX (Ocean Drilling Program).

${ }^{2}$ Department of Geology, University of Sydney, New South Wales 2006, Australia.
1). "Downstream" in this case means to lie farther away from the presumed hotspot source in the direction of plate motion. For example, Woden-Kopakut and Lobbadede guyots lie $5.5^{\circ}$ and $2^{\circ}$ northwest of Lokkworkwor and Wodejebato guyots, respectively. Yet both of these edifices are younger than their more southerly counterparts. The UjlanAnewetak cluster of volcanoes also exhibits a transposition of edifice ages in which Lo-En Guyot is $\sim 36$ m.y. older than the edifice beneath the more northwesterly Anewetak Atoll (Pringle, 1992; Premoli Silva, Haggerty, Rack, et al., 1993; Pringle and Duncan, this volume).

Shallow-water limestones recovered from various summit plateaus in the Marshall Islands also suggest multiple periods of plate uplift and subsidence. Lincoln et al. (1993) postulated that two distinct episodes of uplift and shallow-water exposure occurred across many of the platforms, resulting in punctuated periods of coral growth: the first during the mid-Cretaceous and another during the Late Cretaceous (Table 2 ). Nearly all the volcanic rocks dated by radiometric methods in the Marshall Islands are of Late Cretaceous age, including some of the guyots identified by Lincoln et al. (1993) as having midCretaceous shallow-water carbonate sediments (Pringle and Staudigel, 1992). Drilling on Limalok, Lo-En, and Wodejebato guyots during Leg 144 also failed to recover any mid-Cretaceous shallow-water carbonate sediments, although the basement age of Lo-En Guyot is $112.8 \pm 1.2$ m.y. old (Premoli Silva, Haggerty, Rack, et al., 1993; Pringle and Duncan, this volume). Accordingly, a number of questions regarding the age, sequence, and duration of volcanism in the Marshall Islands still exist.

In an attempt to identify the hotspots responsible for the two apparent episodes of uplift in the Marshall Islands, Lincoln et al. (1993) used a method similar to Duncan and Clague (1985) for rotating dated edifices back through time to their region of construction. In the case of the Marshall Islands, this region is French Polynesia. Smith et al. (1989) also used this technique to "backtrack" Himu and Hemler guyots in the Magellan Seamounts and Woden-Kopakut and Lokkworkwor guyots in the Marshall Islands. Both Lincoln et al. (1993) and Smith et al. (1989) agreed that the proposed hotspots beneath Rurutu and Rarotonga influenced the development of the Marshall Islands, although neither group of authors went so far as to identify specific hotspot trends through either the Ratak or Ralik chains. For example, even though Smith et al. (1989) successfully rotated Woden-Kopakut Guyot back to an area near the present-day Rurutu hotspot, they were unable to identify a hotspot directly responsible for Lokkworkwor. In a similar manner, Lincoln et al. (1993) suggested that the fossil-dated mid-Cretaceous edifices formed near 


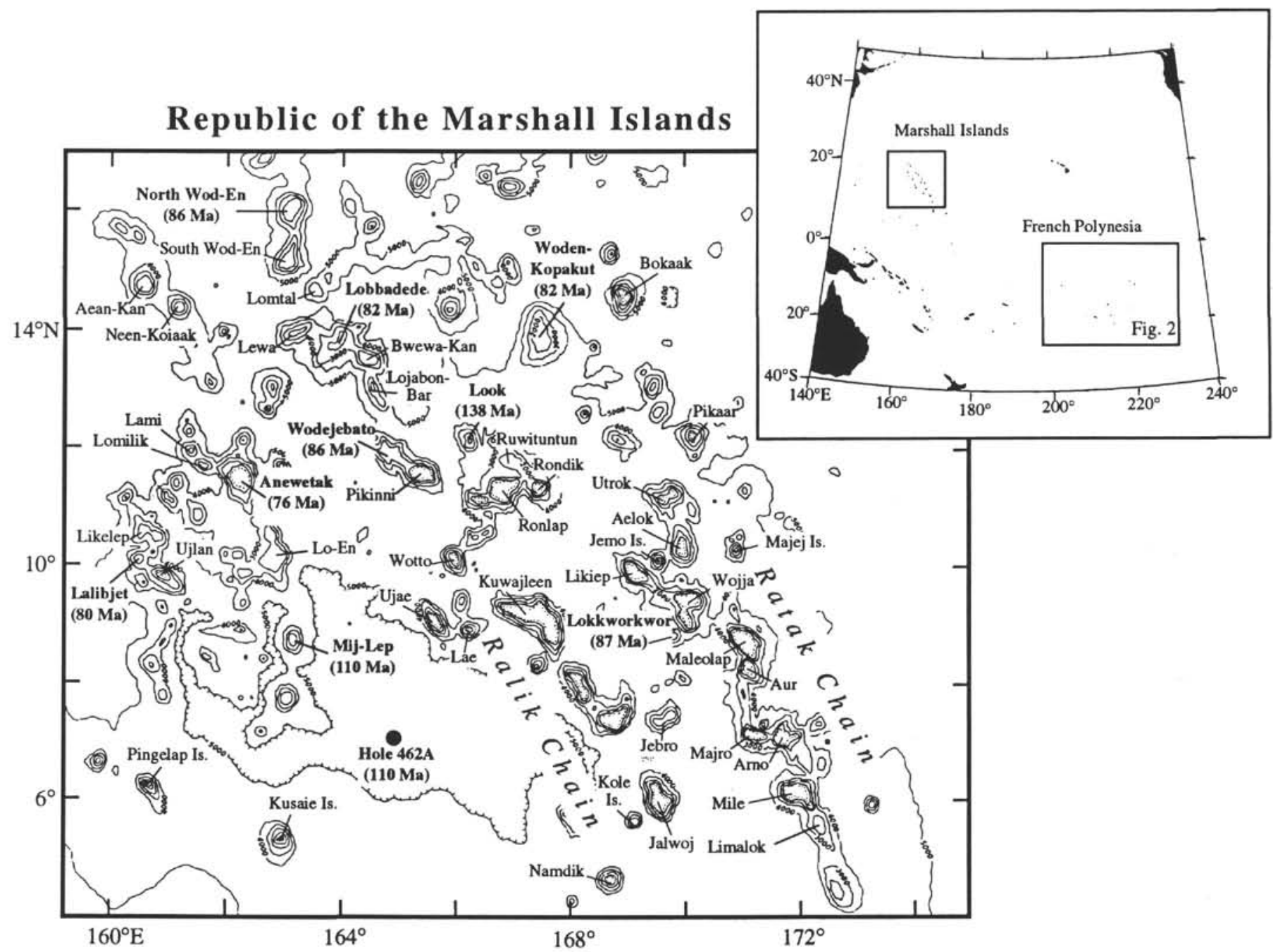

Figure 1. Base map of the Marshall Islands showing selected edifice names and ages, and the two formally recognized volcanic chains in this area. Radiometric ages shown in this figure come from Davis et al. (1987), Lincoln et al. (1993), Pringle (1992), and Pringle and Duncan (this volume). Bathymetry map revised from Hein et al. (1990).

Table 1. Radiometric ages for edifices in the Marshall Islands.

\begin{tabular}{lccc}
\hline \multicolumn{1}{c}{ Edifice } & $\begin{array}{c}\text { Latitude } \\
(\mathrm{N})\end{array}$ & $\begin{array}{c}\text { Longitude } \\
(\mathrm{E})\end{array}$ & $\begin{array}{c}\text { Age } \\
(\mathrm{m} . \mathrm{y})\end{array}$ \\
\hline Lokkworkwor Guyot & $8^{\circ} 51^{\prime}$ & $169^{\circ} 45^{\prime}$ & $86.7-87.9^{\mathrm{a}}$ \\
Woden-Kopakut Guyot & $14^{\circ} 00^{\prime}$ & $167^{\circ} 27^{\prime}$ & $80.6-83.8^{\mathrm{a}}$ \\
Look Guyot & $12^{\circ} 12^{\prime}$ & $166^{\circ} 09^{\prime}$ & $137.7-138.7^{\mathrm{b}}$ \\
Lobbadede Guyot & $13^{\circ} 51^{\prime}$ & $163^{\circ} 54^{\prime}$ & $80.0-84.8^{\mathrm{b}}$ \\
North Wod-En Guyot & $16^{\circ} 06^{\prime}$ & $163^{\circ} 03^{\prime}$ & $84.9-85.7^{\mathrm{b}}$ \\
Lalibjet Guyot & $10^{\circ} 06^{\prime}$ & $160^{\circ} 26^{\prime}$ & $81.4-82.8^{\mathrm{b}}$ \\
Anewetak Atoll & $11^{\circ} 33^{\prime}$ & $162^{\circ} 10^{\prime}$ & $75.3-76.5^{\mathrm{b}}$ \\
Lo-En Guyot & $10^{\circ} 09^{\prime}$ & $162^{\circ} 48^{\prime}$ & $111.6-114.0^{\mathrm{c}}$ \\
Wodejebato Guyot & $11^{\circ} 55^{\prime}$ & $164^{\circ} 51^{\mathrm{c}}$ & $85.0-87.0^{\mathrm{c}}$ \\
& & & $82.1-84.3^{\mathrm{c}}$ \\
& & & \\
\hline
\end{tabular}

Note: References are as follows: $\mathrm{a}=$ Davis et al. (1989); $\mathrm{b}=$ Lincoln et al. (1993) and Pringle (1992); and $c=$ Pringle and Duncan (this volume).

the Macdonald hotspot, and that the Late Cretaceous volcanism and uplift was probably attributable to a combination of the Rurutu, Rarotonga, and Tahiti hotspots; they did not extend their analysis to show linear trends within the Marshall Islands.

All previous studies have focused on rotating individual edifices back to presently active hotspots in French Polynesia. The lithosphere in this area of the southeast Pacific is mechanically thinner (and shal- lower) than normal lithosphere, and hence more susceptible to hotspot penetration (the Superswell; McNutt and Fischer, 1987). Given the record of rejuvenescent volcanism in French Polynesia, especially within the Cook-Austral chain (Duncan and McDougall, 1976; McNutt and Menard, 1978; Turner and Jarrard, 1982), one can see how the transposition of edifice ages may occur and how the record of an older carbonate platform may be partially or totally erased through uplift, subaerial erosion, and truncation. Precise understanding of the history of volcanism within these lineaments may be confused by (1) the errors and uncertainties associated with such dating techniques as fossils vs. radioisotopes, and $\mathrm{K} / \mathrm{Ar}$ dating vs. ${ }^{40} \mathrm{Ar} /{ }^{39} \mathrm{Ar}$ dating (among others, Pringle, 1992); (2) the variable duration of volcanism beyond the shield-building stage (e.g., Clague and Dalrymple, 1987); (3) the variable length of time separating edifice construction, summit truncation, and coral colonization (e.g., Bardintzeff et al., 1985); and (4) the uncertainties in calculation of stage poles and rotation angles back through the Cretaceous (e.g., Morgan, 1972; Epp, 1978; Duncan and Clague, 1985; Engebretson et al., 1985; Yan and Kroenke, 1993).

In this paper, I attempt to identify Cretaceous hotspot tracks through the Marshall Islands by treating the assorted guyots, atolls, and islands as members of hotspot chains rather than as individual edifices. After the hypothetical trends have been tested against the available age information, the focus of the paper shifts to understanding the implications of misfits between the modeled tracks and 
Table 2. Fossil ages for edifices in the Marshall Islands.

\begin{tabular}{lccl}
\hline \multicolumn{1}{c}{ Edifice } & $\begin{array}{c}\text { Latitude } \\
(\mathrm{N})\end{array}$ & $\begin{array}{c}\text { Longitude } \\
\text { (E) }\end{array}$ & \\
\hline Wodejebato Guyot & $11^{\circ} 55^{\prime}$ & $164^{\circ} 51^{\prime}$ & Fpssil evidence \\
Ruwituntun Guyot & $11^{\circ} 54^{\prime}$ & $166^{\circ} 57^{\prime}$ & Ulber Campanian to middle Maastrichtian (see Camoin et al., Erba and Watkins, Premoli Silva et al., all in this volume) \\
Lo-En Guyot & $10^{\circ} 09^{\prime}$ & $162^{\circ} 48^{\prime}$ & Albian- to Cenomants in Late Cretaceous foraminifer matrix \\
Lalibjet Guyot & $10^{\circ} 06^{\prime}$ & $160^{\circ} 26^{\prime}$ & Basalt breccia within a Late Cretaceous foraminifer matrix \\
Lobbadede Guyot & $13^{\circ} 51^{\prime}$ & $163^{\circ} 54^{\prime}$ & Phosphatized limestones containing Cenomanian- to Campanian-age planktonic foraminifers \\
Lewa Guyot & $14^{\circ} 00^{\prime}$ & $163^{\circ} 12^{\prime}$ & Ooidic limestone conglomerate in a matrix of Albian- to Cenomanian-age foraminifers. \\
Lomtal Guyot & $14^{\circ} 47^{\prime}$ & $163^{\circ} 30^{\prime}$ & Basalt conglomeratein a phosphatized Santonian-age (?) foraminifer (poorly preserved) \\
Limalok Guyot & $5^{\circ} 42^{\prime}$ & $172^{\circ} 12^{\prime}$ & Late Paleocene to middle Eocene (see Nicora et al., this volume) \\
\hline
\end{tabular}

Note: All ages other than those noted in the table are from Lincoln (1990) and Lincoln et al. (1993).

the observed data, in particular, the longevity and the fixity of hotspots during the construction of the Marshall Islands.

\section{METHODOLOGY}

A number of assumptions are inherent in any model attempting to identify hotspot trends through the Marshall Islands. These assumptions include the following.

1. The edifices composing the Marshall Islands result from midplate volcanism over hotspots. This assumption excludes such catastrophic tectonic events as large-scale fracturing of the plate (Menard, 1964), or the simultaneous construction of volcanoes along "hot lines" (Bonatti et al., 1977).

2. Hotspots are upper mantle, thermal anomalies maintained by relatively long-lived, deep-seated mantle plumes capable of creating discrete chains of volcanoes. The geometry of these volcanic island chains records changes in plate motions through time, and the age progression along a chain indicates the rate of plate motion relative to the fixed hotspot source.

3. The four hotspots postulated to be influencing the Cook-Austral and Society chains also were active in the Cretaceous, and their geographic location has remained fixed.

The third assumption requires some additional discussion as the data supporting the existence of each French Polynesian hotspot varies substantially.

Two well-defined, northwest-trending chains of volcanoes, the Cook-Austral Islands and the Society Islands, mark the western extent of French Polynesia (Fig. 2). Macdonald Seamount lies at the southeastern end of the Austral chain and marks the site of active volcanism in this island group (Table 3). Edifices within the Austral chain increase linearly in age up to Rurutu Island, where young volcanic rocks lie superimposed on an older shield volcano (Duncan and McDougall, 1976; Turner and Jarrard, 1982). The volcanic rocks of this island record two episodes of volcanism separated by $\sim 10$ m.y., whereas the island itself consists of a single shield volcano surrounded by $100-\mathrm{m}$-high cliffs of shallow-water carbonates. A number of uplifted atolls lie to the northwest of Rurutu, forming for the most part the southern Cook Islands (Fig. 2). Volcanic rocks dated from these uplifted edifices show a linear age progression away from the young volcanism recorded at Rurutu (Table 3).

The uplifted atolls, on the other hand, suggest that the underlying volcanic platform is related to an older episode of volcanism, perhaps associated with the Macdonald hotspot, as sufficient time must have passed since edifice construction to allow for subsidence and the accumulation of shallow-water carbonate sediments. Rarotonga Island lies to the southwest of the Cook Islands and is yet another site of recent (1.1-1.7 m.y.; Table 3) volcanism (Jarrard and Turner, 1979; Matsuda et al., 1984). In a geomorphic sense, the island appears to be young with very little reef along its shores, but the seafloor in the surrounding area shows no topographic evidence for the passage of a hotspot (either to the northwest or to the southeast of this edifice).
The fourth hotspot proposed for this region is located southeast of Tahiti in the Society chain (Fig. 2). The Society (or Mehetia) hotspot consists of at least five centers of volcanic and hydrothermal activity encompassing an area of approximately $8000 \mathrm{~km}^{2}$ (Cheminee et al., 1989; Stoffers et al., 1989). The Society chain exhibits a simple linear age progression in the direction of plate motion (Table 3), extending from Mehetia Seamount in the southeast to at least Motu One Island in the northwest (Duncan and McDougall, 1976). The Macdonald and Society hotspots appear to have been active for at least the past 20 m.y. and probably longer (Duncan and McDougall, 1976; Turner and Jarrard, 1982). Accordingly, they are given the highest priority when attempting to match hotspot tracks in the Marshall Islands to the observed topography and age data.

The proposed Rurutu hotspot also seems to have played a relatively important role in the development of the Cook Islands, but the scarcity of data on and around this edifice make it less attractive as a long-lived hotspot than Macdonald and Society. Rarotonga Island, albeit young, shows very little evidence for being directly related to hotspot activity and, hence, receives the least consideration throughout the modeling. Other hotspots have been proposed for this area (e.g., Raevavae and Aitutaki; Fleitout and Moriceau, 1992), but these four appear to have the best support with respect to young or active volcanism.

If one accepts the assumptions as listed above, then a simple model for identifying hotspot tracks through the Marshall Islands can be constructed. The first step toward constructing this model is to plot the topography of the Marshall Islands in oblique Mercator projections. In these projections, the pole of the projection is the stage pole defining Pacific Plate motion relative to hotspots. Such projections force features created during the time interval of the stage pole to lie on horizontal lines of latitude about the pole. Consequently, all volcanoes constructed over a stationary hotspot source during a particular stage pole interval will form horizontal lines in the projection. A number of stage poles describing Pacific Plate motion relative to hotspots exist in the literature. In this paper, I initially examine three groups (Table 4). The poles listed in Duncan and Clague (1985) and Henderson (1985) were used by Lincoln et al. (1993) to track guyots in the Marshall Islands, and they are used in this paper to remain consistent with Lincoln et al.'s models. The Engebretson et al. (1985) poles were derived from global plate circuits as part of a project to describe the displacement history between western North America, eastern Eurasia, and adjacent oceanic plates (Pacific, Farallon, Izanagi, Kula, and Phoenix).

All three groups of poles are in relative agreement back to about $78 \mathrm{Ma}$ (Fig. 3). The Hawaiian chain provides good control on Pacific Plate motion from 0 to $43 \mathrm{Ma}$ (e.g., Morgan, 1972; Jarrard and Clague, 1977; Minster and Jordan, 1978; Turner et al., 1980). In a similar fashion, the Emperor chain provides good constraints on Pacific Plate motion relative to hotspots for the time period extending from 43 to $78 \mathrm{Ma}$ (Clague and Jarrard, 1973; Epp, 1978; Henderson and Gordon, 1981). Differences in the stage duration and the angle of rotation for this time interval (Table 4) result from choosing different edifices marking the change of plate motion in the northern Emperor chain. Henderson (1985) used Detroit Tablemount, whereas the other 


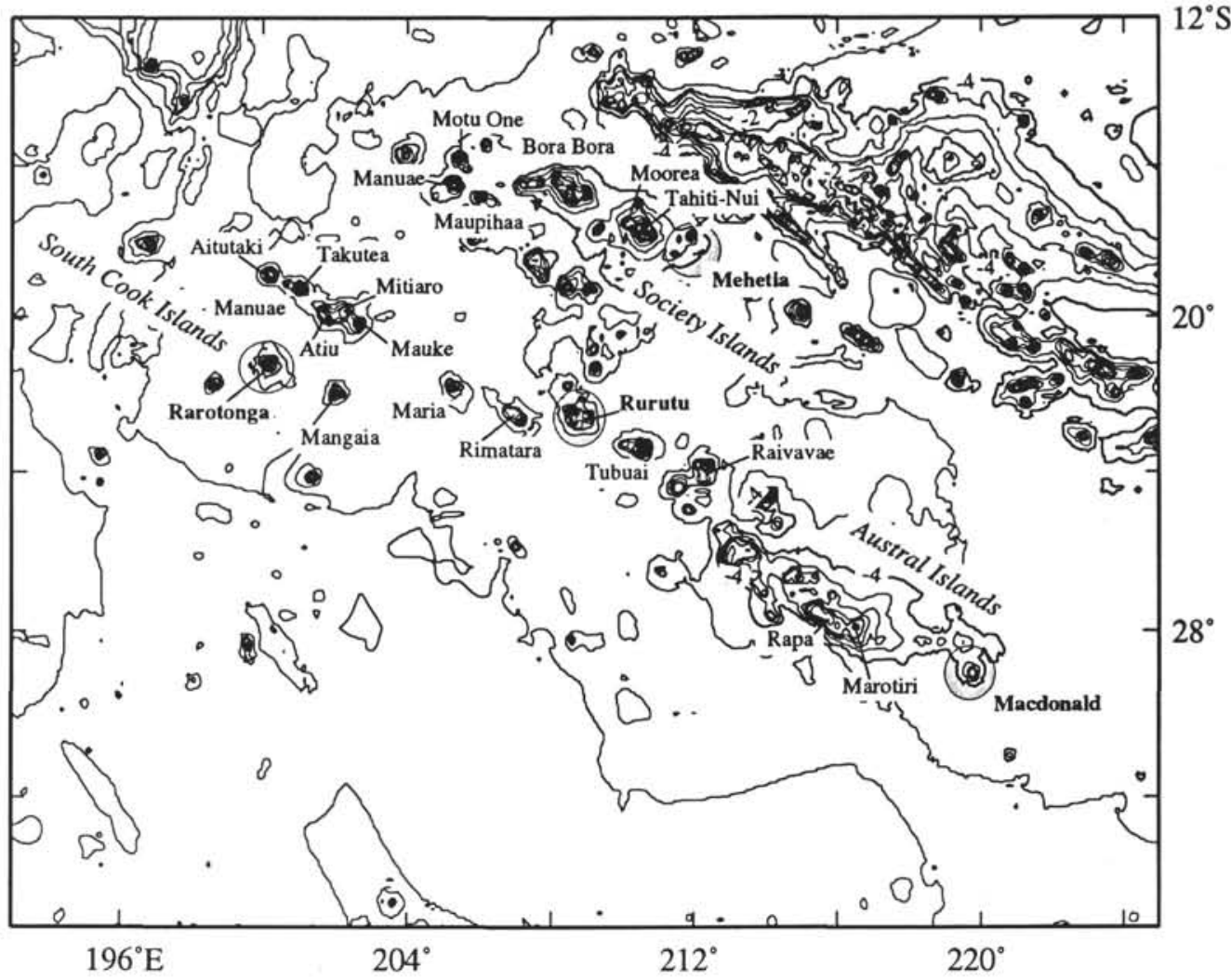

Figure 2. Bathymetry of the Cook-Austral Islands and the Society Islands. This map shows the location of hotspots discussed in this paper and the alignment of edifices associated with each hotspot.

Table 3. Descriptions of selected French Polynesia hotspot chains.

\begin{tabular}{|c|c|c|c|}
\hline & $\begin{array}{l}\text { Radiometric ages } \\
\text { (m.y.) }\end{array}$ & $\begin{array}{l}\text { Hotspot distance } \\
(\mathrm{km})\end{array}$ & Comments \\
\hline Austral Islands: & & & \\
\hline Macdonald & 0 & 0 & \\
\hline Rapa & $5.1 \pm 0.3^{\mathrm{e}}$ & 405.9 & Horseshoe-shaped eroded caldera surrounded by very little reef. \\
\hline Raivavae & $5.5-7.3^{\mathrm{d}}$ & 888.0 & Elongated island $460 \mathrm{~m}$ high surrounded by barrier reef. \\
\hline Tubuai & $8.6-10.4^{d}$ & 1062.9 & Elliptical island surrounded by barrier reef. \\
\hline \multicolumn{4}{|l|}{ South Cook Islands: } \\
\hline Rurutu & $\begin{array}{c}1.06-1.12^{\mathrm{c}} \\
12.08-12.56^{\mathrm{c} . \mathrm{d}}\end{array}$ & 0 & Uplifted remnant of shield volcano surrounded by 100 -m-high coral reef. \\
\hline Rimatara & $\begin{array}{c}>4.78 \pm 0.42^{c} \\
20.6-29.9^{c}\end{array}$ & 180.3 & Uplifted atoll with $83-\mathrm{m}$-high volcanic summit and $11-\mathrm{m}$-high makatea. \\
\hline Maria & -1 & 374.7 & \\
\hline Mauke & $\begin{aligned} 4.64 & \pm 0.14^{\mathrm{c}} \\
6.3 & \pm 0.2^{\mathrm{c}}\end{aligned}$ & 671.7 & Uplifted atoll with flat summit $(29 \mathrm{~m})$ surrounded by 24 -m-high makatea. \\
\hline Mitiaro & $>12.3 \pm 0.42^{\mathrm{c}}$ & 716.1 & Uplifted atoll with $12-\mathrm{m}$-high volcanic hills and a 15 -m-high makatea rim \\
\hline Atiu & $\begin{array}{c}8.0-8.5^{\mathrm{c}} \\
-10^{\mathrm{c}}\end{array}$ & 743.7 & Uplifted atoll showing two episodes of volcanism. \\
\hline Aitutaki & $\begin{array}{c}7.39 \text { to }>8.73^{c} \\
0.7-1.9^{\mathrm{c}}\end{array}$ & 951.0 & Very nearly an atoll with relatively large carbonate platform. \\
\hline Mangaia & $16.2-19.8^{\mathrm{b}, \mathrm{c}}$ & -191.4 & Uplifted atoll with $169-\mathrm{m}$-high volcanic summit and 90 -m-high limestone rim. \\
\hline Raratonga & $\begin{array}{l}1.6-2.3^{\mathrm{c}} \\
1.4 \pm 0.3^{\mathrm{a}}\end{array}$ & 0 & Geomorphically young island showing very little reef development. \\
\hline \multicolumn{4}{|l|}{ Society Islands: } \\
\hline Mehetia & 0 & 0 & \\
\hline Tahiti-Nui & $0.4-1.2^{\mathrm{d}, \mathrm{f}}$ & 39.0 & Maximum elevation of $2241 \mathrm{~m}$. \\
\hline Tahiti-Iti & $<0.5^{\mathrm{d}}$ & 69.3 & Total island length for Tahiti is around $65 \mathrm{~km}$. \\
\hline Moorea & $1.49-1.64^{\mathrm{d}}$ & 108.3 & Approximately one third of the cone appears to have eroded away. \\
\hline Huahine & $2.01-2.58^{\mathrm{d}}$ & 244.2 & Consists of twin islets formed by the faulting of a single cone. \\
\hline Raiatea & $>2.45^{\mathrm{d}}$ & 283.2 & Triangular in shape, rising to a maximum elevation of $1033 \mathrm{~m}$. \\
\hline Tahaa & $2.56-3.16^{\mathrm{d}}$ & 294.3 & Initiation of volcanism coincides with volcanism on Bora Bora. \\
\hline Bora Bora & $3.12-3.51^{\mathrm{d}}$ & 321.9 & Type example of a barrier reef as described by Darwin. \\
\hline Maupiti & $3.94-4.34^{\mathrm{d}}$ & 391.2 & Caldera may have lain to the south of the island. \\
\hline
\end{tabular}

Notes: References are as follows: $\mathrm{a}=$ Matsuda et al. (1984), b= Dalrymple et al. (1975), $\mathrm{c}=$ Turner and Jarrard (1982), $\mathrm{d}=$ Duncan and Mcdougall (1976), and e = Krummenacher and

Noetzlin (1966). All ages are based on $\mathrm{K} / \mathrm{Ar}$ dating techniques, with the exception of the one $\mathrm{Ar}^{40} / \mathrm{Ar}^{39}$ age from Matsuda et al. (1984). 


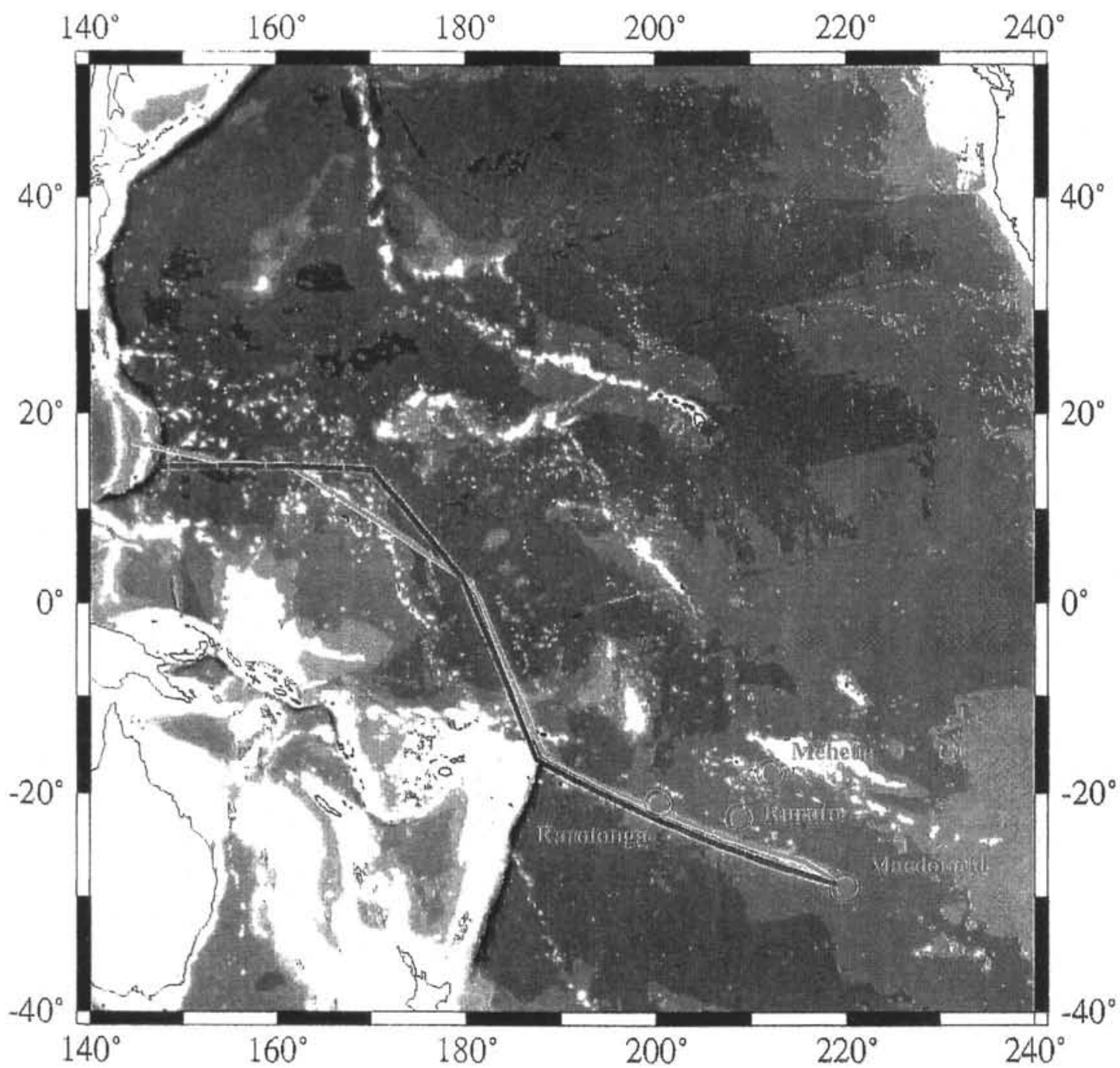

Figure 3. Map showing the variations in stage poles and angles of rotation used by Engebretson et al. (1985), Duncan and Clague (1985), and Henderson (1985). The white track represents the Engebretson et al. stage poles, and the black track represents the Duncan and Clague stage poles. The track for the Henderson stage poles closely parallels that for the Duncan and Clague stage poles. All the poles are in agreement to approximately $78 \mathrm{Ma}$, after which the Engebretson et al. (1985) plate rotations diverge from other two sets of poles.

two groups used Tenji Seamount. The pre-78 Ma stage pole and angle of rotation used by Engebretson et al. (1985) differs substantially from those used by the other two groups (Fig. 3 and Table 4).

Duncan and Clague (1985) and Henderson (1985) used the stage pole of Epp (1978), found by fitting small circles to three northweststriking seamount chains north of the Hawaiian chain. The stage pole listed by Engebretson et al. (1985, p. 7) is quite different from the Epp pole, as is the angle of rotation (almost $9^{\circ}$ more than that suggested by Epp [1978]). Consequently, I eliminated this set of stage poles from the present analysis. The other two groups have only slight differences in the angle of rotation and duration of the stage period. The Henderson (1985) rotation angle compromises between placing the Line Islands-Line Cross trend intersection over the Easter hotspot and the Hess Rise over the Marquesas hotspot. Duncan and Clague (1985) propose slightly less rotation than Epp (1978). The constraints on stage pole estimates for pre-100 Ma plate motions are very poor.

The Mid-Pacific Mountains and Hess Rise appear to be the most reliable recorders of plate motion during this time interval, but the paucity of ages for edifices in these two volcanic provinces makes estimated stage poles and rotation angles dubious. Duncan and Clague (1985) used a single stage pole extending from 100 to $150 \mathrm{Ma}$, whereas Henderson (1985) defined two substage poles at 97-130 Ma and
130-150 Ma (hence, dividing the Mid-Pacific Mountains and Hess Rise into more realistic two-trend volcanic chains). With the two sets of stage pole estimates of Duncan and Clague (1985) and Henderson (1985), hypothetical hotspot tracks for Macdonald, Society, Rurutu, and Rarotonga can be traced across the Pacific Plate for the period extending from 42 to $<100 \mathrm{Ma}$.

\section{MODEL RESULTS}

Oblique Mercator projections using the 74-100 Ma stage pole of Duncan and Clague (1985) and the 78-97 Ma stage pole of Henderson (1985) show general trends within the Marshall Islands (Fig. 4). A number of observations are possible from these projections, assuming completely stationary hotspots (for this discussion I primarily use the Duncan and Clague stage intervals).

1. The Rurutu hotspot appears to be responsible for the construction of much of the Ratak Chain back through the 74-100 Ma stage pole period.

2. The 100-150 Ma portion of the Macdonald hotspot track crosses the northern Marshall Islands.

3. The Ujlan-Anewetak group of edifices may be linked by the Rarotonga hotspot. 
Table 4. Stage poles for Pacific Plate motion relative to hotspots.

\begin{tabular}{|c|c|c|c|c|}
\hline & $\begin{array}{l}\text { Latitude } \\
\text { (N) }\end{array}$ & $\begin{array}{l}\text { Longitude } \\
\text { (E) }\end{array}$ & $\begin{array}{c}\text { Angle } \\
\left({ }^{\circ}\right)\end{array}$ & Reference \\
\hline \multicolumn{5}{|c|}{ Henderson (1985) model: } \\
\hline $0-5 \mathrm{Ma}$ & $61^{\circ} 42^{\prime}$ & $277^{\circ} 30^{\prime}$ & 4.8 & Minster and Jordan (1978) \\
\hline $0-43 \mathrm{Ma}$ & $67^{\circ} 00^{\prime}$ & $287^{\circ} 00^{\prime}$ & 34.0 & Morgan (1972) \\
\hline $43-78 \mathrm{Ma}$ & $17^{\circ} 00^{\prime}$ & $253^{\circ} 00^{\prime}$ & 19.0 & Clague and Jarrard (1973) \\
\hline $78-97 \mathrm{Ma}$ & $36^{\circ} 00^{\circ}$ & $284^{\circ} 00^{\prime}$ & 15.5 & Ерp (1978) \\
\hline $97-130 \mathrm{Ma}$ & $70^{\circ} 00^{\prime}$ & $289^{\circ} 00^{\prime}$ & 13.0 & Henderson (1985) \\
\hline \multicolumn{5}{|c|}{ Engebretson et al. (1985) model: } \\
\hline $0-5 \mathrm{Ma}$ & $57^{\circ} 00^{\prime}$ & $285^{\circ} 00^{\prime}$ & 4.7 & Minster and Jordan (1978) \\
\hline $5-43 \mathrm{Ma}$ & $69^{\circ} 00^{\prime}$ & $289^{\circ} 00^{\prime}$ & 18.2 & Jarrard and Clague (1977) \\
\hline $43-74 \mathrm{Ma}$ & $22^{\circ} 00^{\prime}$ & $269^{\circ} 00^{\prime}$ & 20.2 & Epp (1978) \\
\hline $74-100 \mathrm{Ma}$ & $48^{\circ} 00^{\prime}$ & $299^{\circ} 00^{\prime}$ & 24.0 & Henderson and Gordon (1981) \\
\hline $100-115 \mathrm{Ma}$ & $68^{\circ} 00^{\prime}$ & $162^{\circ} 00^{\prime}$ & 8.0 & Henderson and Gordon (1981) \\
\hline $115-135 \mathrm{Ma}$ & $75^{\circ} 00^{\prime}$ & $273^{\circ} 00^{\prime}$ & 10.0 & Henderson and Gordon (1981) \\
\hline \multicolumn{5}{|c|}{ Duncan and Clague (1985) model: } \\
\hline $0-42 \mathrm{Ma}$ & $68^{\circ} 00^{\prime}$ & $285^{\circ} 00^{\prime}$ & 34.0 & Duncan and Clague (1985) \\
\hline $42-65 \mathrm{Ma}$ & $17^{\circ} 00^{\prime}$ & $253^{\circ} 00^{\prime}$ & 14.0 & Jarrard and Clague (1977) \\
\hline $65-74 \mathrm{Ma}$ & $22^{\circ} 00^{\prime}$ & $265^{\circ} 00^{\prime}$ & 7.5 & Duncan and Clague (1985) \\
\hline $74-100 \mathrm{Ma}$ & $36^{\circ} 00^{\prime}$ & $284^{\circ} 00^{\prime}$ & 15.0 & Duncan and Clague (1985) \\
\hline $100-150 \mathrm{Ma}$ & $85^{\circ} 00^{\prime}$ & $165^{\circ} 00^{\prime}$ & 24.0 & Duncan and Clague (1985) \\
\hline
\end{tabular}

Note: Stage intervals in italics show the poles that differ substantially among the three models.

4. Society hotspot was apparently inactive or failed to penetrate the lithosphere at this time as no topography marks its passage.

5. A considerable number of edifices lie off the tracks from these four hotspots.

On the basis of the oblique projections shown in Figures $4 \mathrm{~A}$ and $4 \mathrm{~B}$, the southern half of the Ratak Chain, up to and including Maleolap Atoll, was constructed during the latest Cretaceous (pre-74 Ma stage poles). The late Paleocene ( 72 Ma; Harland et al., 1990) fossil age assigned to the base of the carbonate platform on Limalok (Nicora et al., this volume) is consistent with this observation, although ${ }^{40} \mathrm{Ar} /{ }^{39} \mathrm{Ar}$ ages for the basalts sampled at Limalok will provide more conclusive evidence once they become available (M. Pringle, pers. comm., 1993).

The alignment of volcanoes within the Ralik Chain in the 74-100 Ma projection (Figs. 1 and 4A) is consistent with the available radiometric age data for the time of their formation, although none of modeled tracks lies directly over this chain nor is it perfectly horizontal. Fossils in limestones recovered during dredging across selected platforms in the northern Ralik Chain are evidence that a number of the edifices existed during the mid-Cretaceous (Lincoln, 1990; Lincoln et al., 1993). The position of the Macdonald hotspot track appears to be consistent with the mid-Cretaceous fossil ages for Lewa, Lobbadede, and Aean-Kan, but the fit of this track is worse using the Henderson (1985) poles (Fig 4B). Neither the Duncan and Clague (1985) nor the Henderson (1985) stage poles produces a track to coincide with the mid-Cretaceous microfossil ages on Wodejebato and Ruwituntun guyots or the Late Cretaceous volcanic ages on Lobbadede or Wodejebato.

In the Ujlan-Anewetak group of edifices, mid-Cretaceous volcanism is interspersed with Late Cretaceous volcanism. The uncertainty of plate rotation parameters before $\sim 90 \mathrm{Ma}$ and only two $>100 \mathrm{Ma}$ radiometric ages in this area precludes any statement concerning plate motion at this time, but the $\sim 76 \mathrm{Ma}$ radiometric age recorded at Anewetak and the $\sim 80 \mathrm{Ma}$ age for Lalibjet coincide well with a change in plate motion around $74 \mathrm{Ma}$ (Fig. 4A).

If we continue to assert that the Marshall Islands formed from hotspot volcanism in French Polynesia, then inconsistencies between the model hotspot tracks and the observed topography and age data require that some of the initial assumptions be revised. For example, in the northern half of the Ratak Chain, Davis et al. (1989) note that the transposition of edifice ages between Lokkworkwor and WodenKopakut suggests a more complicated history of volcanism than usually associated with a single hotspot. Although the $82 \mathrm{~m}$.y. age appears appropriate for the hotspot track from Rurutu, the $87 \mathrm{~m}$.y. age at Lokkworkwor is clearly too old. The two assumptions most amenable to revision are the duration of hotspot activity (and perhaps the number of hotspots) and the degree to which hotspots remain stationary relative to one another.

\section{DURATION AND FIXITY OF HOTSPOTS}

Fluctuations in the strength of the mantle plume and changes in the thickness of the lithosphere influence the duration over which a hotspot leaves a topographic expression on the seafloor, and provides perhaps the easiest means of explaining anomalous linear trends of seafloor topography (or lack thereof). Under such conditions, every chain of volcanoes not accounted for by a presently active hotspot (e.g., the Ralik Chain) could result from the penetration of a former, but presently dormant, hotspot through the lithosphere. In the same respect, every modeled hotspot track not showing a physical trace on the seafloor could simply result from the absence of a plume during that particular time or an impenetrable portion of the lithosphere. Under such conditions, the number of hotspots active beneath French Polynesia may be greater than currently accepted (Fleitout and Moriceau, 1992) or the life span of magma production from mantle plumes in this region may be shorter than that observed for the Hawaiian and Louisville hotspots (Staudigel et al., 1991; Pringle, 1992). Varying the strength of mantle plumes or the lithosphere to match seafloor topography has the undesirable implication of diminishing the role of hotspots as long-term recorders of plate motion history, but hotspots do wax and wane through time (e.g., Detrick et al., 1986; Lonsdale, 1988; Sleep, 1990).

Staudigel et al. (1991) show that the isotopic and thermal anomaly characteristics of the present-day south Pacific (SOPITA, an area including French Polynesia) are also recorded in the Cretaceous-age western Pacific edifices. As the thermal anomaly of the SOPITA area is elongated in a west-northwest direction, Staudigel et al. (1991) attribute changes in plate motion, from more westerly to northwesterly, to explain the absence of physical traces of hotspot activity between French Polynesia and the western Pacific (a larger cross section of the lithosphere moves over the thermal anomaly during northwesterly plate motion). Presumably, the present-day northwest motion of the Pacific Plate contributes to the relatively short duration of hotspot activity recorded by the French Polynesian chains, none of which is older than $\sim 30 \mathrm{~m}$.y.

The alternative mechanism to explain misfits between the modeled hotspot tracks and the linear Marshall Islands chains is hotspot wander through time. The wander of Atlantic Ocean hotspots relative to Indian Ocean hotspots has been examined in a number of papers (e.g., Duncan, 1981; Morgan, 1981, 1983; Duncan and Richards, 1991). The general consensus from these studies is that the maximum rate of hotspot wander approaches $5 \mathrm{~mm} / \mathrm{yr}$ over periods of $120 \mathrm{~m} . \mathrm{y}$., although this wander does not appear to be in a preferential direction. Constraints on the motion between Pacific hotspots are fewer because subduction zones isolate the plates in this basin from the global plate motion circuit except through Antarctica. Molnar and Stock (1987) postulated that the Hawaiian hotspot has moved southward 10-20 $\mathrm{mm} / \mathrm{yr}$ with respect to hotspot traces in the Atlantic and Indian oceans, but they did not account for deformation between East and West Antarctica. On the basis of paleolatitude estimates from magnetic data, Gordon and Cape (1981) and Sager and Bleil (1987) suggest $10^{\circ}-12^{\circ}$ of southward drift of the Pacific hotspots relative to the spin axis since the Late Cretaceous. A similar conclusion was reached by Winterer et al. (1993); they attributed the difference between the paleolatitude estimates for the Japanese and Marcus-Wake seamounts $\left(2^{\circ}-10^{\circ}\right)$ and the present location of the Superswell hotspots $\left(\sim 30^{\circ}\right)$ to southward displacement or shrinking of this anomalous mantle region since the mid-Cretaceous.

Estimating the rates and the direction of hotspot wander requires good paleolatitude estimates and age constraints across a number of edifices in a volcanic chain; such data do not yet exist for the Marshall 
A
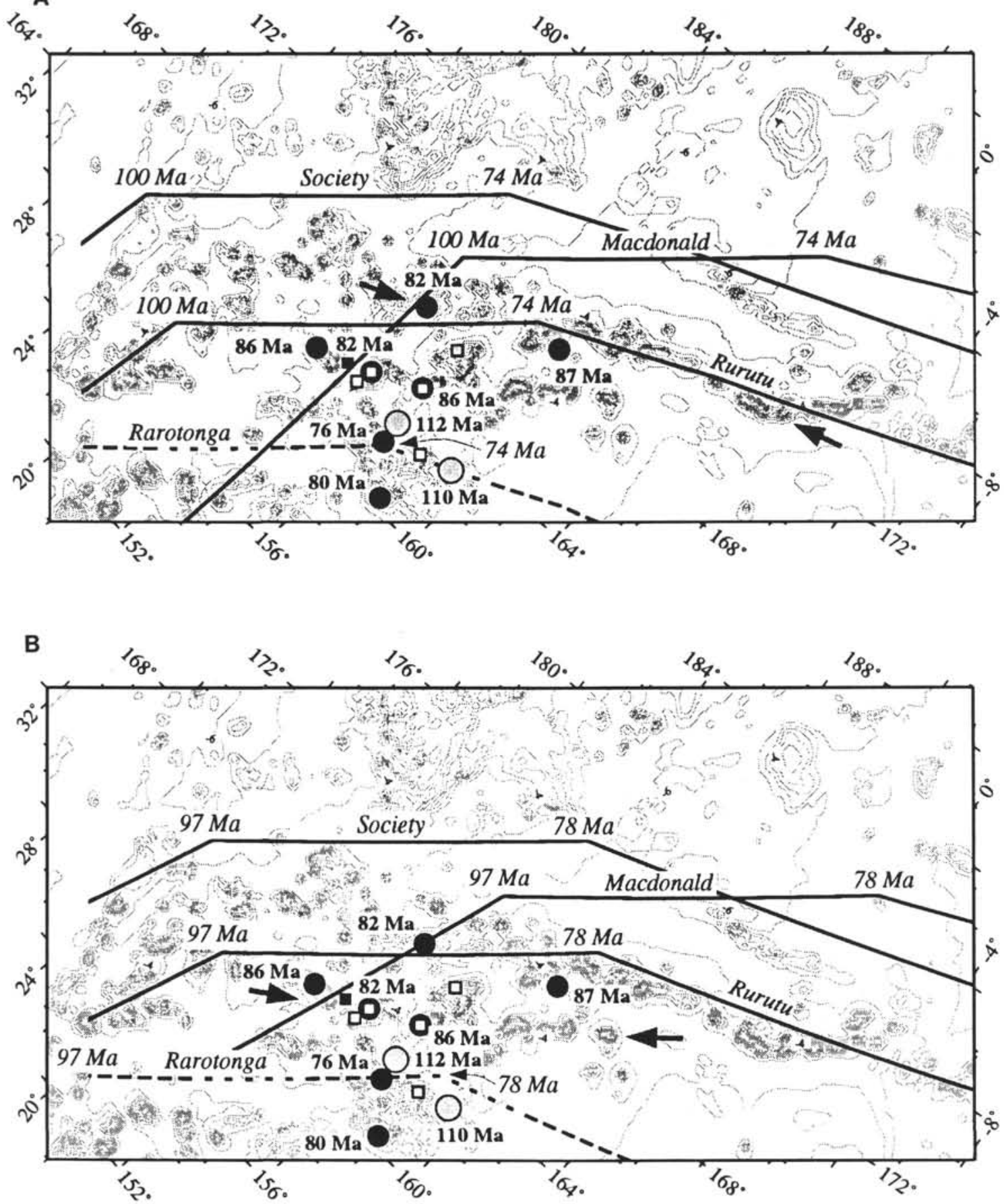

Figure 4. Oblique mercator projections using the stage poles of (A) Duncan and Clague (1985) and (B) Henderson (1985). The projections show the general correspondence between stationary hotspots in French Polynesia and the edifices composing the Marshall Islands. Dark symbols represent ages $<90$ m.y. whereas gray symbols represent ages $>90 \mathrm{~m}$.y. Circles represent radiometric ages $\left(\mathrm{K} / \mathrm{Ar}\right.$ and $\left.{ }^{40} \mathrm{Ar} /{ }^{39} \mathrm{Ar}\right)$ and squares represent fossil ages (see references in Tables 1 and 2). The arrows in Figures $4 \mathrm{~A}$ and $4 \mathrm{~B}$ show the approximate extent of the Ratak and Ralik chains, respectively, as defined in the text (see also Fig. 1).

Islands. The few radiometric and fossil ages that do exist suggest that scattered mid-Cretaceous volcanism was overprinted by Late Cretaceous volcanism. On the basis of volcanism recorded in French Polynesia and the hotspot track modeling presented here, the Macdonald hotspot is the most likely candidate for the mid-Cretaceous volcanism in the Marshall Islands, although no physical trace for the passage of this hotspot is apparent in the bathymetry for the interval extending from $\sim 100$ to $\sim 10 \mathrm{Ma}$ (assuming that the Macdonald hotspot is responsible for the southern Cook Islands). Given our present poor understanding of plate motions relative to hotspots before $\sim 90 \mathrm{Ma}$ and the relatively sparse age data in the Marshall Islands, further modeling to match the Macdonald hotspot track to the available mid-Cretaceous ages (e.g., through hotspot wander) is unwarranted.

At present, no single model adequately explains the observed distribution of edifice ages in the Marshall Islands without applying some tenuous assumptions regarding the longevity or fixity of hotspots. If we are willing to accept that hotspots other than those presently identified in French Polynesia were active during the Cre- 
taceous, then matching ages to linear trends in the edifices is a fairly straightforward process: the Rurutu hotspot formed the Ratak Chain, and unidentified hotspots constructed the mid-Cretaceous edifices in the northern Ralik Chain, the cluster of edifices in the UjlanAnewetak group, and the portion of the Ralik Chain in the $\sim 74-100$ Ma stage. In none of these cases does the physical expression of the hotspot unambiguously extend back to the area of French Polynesia. If, on the other hand, the presently existing hotspot reference frame in French Polynesia applies to the Cretaceous, then hotspot wander must have occurred. In this case, the Macdonald hotspot could be responsible for mid-Cretaceous volcanism in the northern Ralik Chain, and the Rarotonga hotspot might be linked to the volcanism in the Ujlan-Anetewak group.

Our understanding of the Superswell and its hotspots strongly influence many of the assumptions concerning hotspot longevity and fixity in the Marshall Islands region. Staudigel et al. (1991) present evidence for the long-term existence of the SOPITA, whereas McNutt and Fischer (1987) argue that the lithosphere over the Superswell is more susceptible than normal lithosphere to hotspot penetration. Little direct information (e.g., chains of seamounts) exists concerning the long-term stability of individual French Polynesian hotspots (the oldest volcanoes dated in either the Cook-Austral or Society chains are $<30$ m.y.). Consequently, making direct links between volcanic chains in the Marshall Islands and hotspots in French Polynesia requires some technique other than the physical traces recorded on the seafloor (perhaps the isotopic abundances or geochemistry of the volcanic rocks).

\section{CONCLUSIONS}

The results of modeling hotspot trends through the Marshall Islands are far from conclusive, but a tentative correspondence between volcanic chains in the Marshall Islands and hotspots in French Polynesia can be established subject to a number of assumptions. The modeling presented here illustrates the following.

1. The Ralik Chain formed during the Duncan and Clague (1985) 74-100 Ma stage, but it does not correspond to any of the existing French Polynesian hotspots.

2. The Macdonald hotspot may have been responsible for midCretaceous volcanism in the northern part of the Ralik Chain.

3. The Ratak Chain formed over the Rurutu hotspot, assuming this hotspot remained stationary.

4. The group of edifices clustered around Anewetak and Ujlan atolls appear to correlate with the Rarotonga hotspot and a change in plate motion around $\sim 74 \mathrm{Ma}$. This age appears to be consistent with the available radiometric ages from this group ( $76 \mathrm{Ma}$ for Anewetak, and $80 \mathrm{Ma}$ for Lalibjet).

Correlation between hotspots associated with the Superswell and volcanic edifices in the Marshall Islands appears promising. In particular, the mid-Cretaceous track of the Macdonald hotspot through this area may permit the calculation of a pre- $100 \mathrm{Ma}$ stage pole for Pacific Plate motion relative to hotspots if more age information can be obtained. The results from the modeling presented in this paper set the stage for a more rigorous examination of hotspot trends and hotspot affinities (e.g., magnetic inversion ages and isotopic signatures of basalts) in the Marshall Islands.

\section{ACKNOWLEDGMENTS}

I thank F. Duennebier, A. Shor, J. Sinton, P. Wessel, R. Wilkens, and $\mathrm{M}$. Pringle for discussions concerning the scope of this study. Critical reviews from R. Duncan, H. Staudigel, and M. McNutt improved the contents of the manuscript. This research was primarily supported by NSF Grant No. OCE-8709568, with additional support from Mokes on Spokes.

\section{REFERENCES}

Bardintzeff, J.M., Brousse, R., and Gachon, A., 1985. Conditions of building of coral reefs on a volcano: Mururoa in Tuamotu and Rurutu in Australes (French Polynesia). Proc. 5th Int. Coral Reef Congr., 6:401-405.

Bonatti, E., Harrison, C.G.A., Fischer, D.E., Honnorez, J., Schilling, G.G., Stipp, J.J., and Zentilli, M., 1977. Easter volcanic chain (Southeast Pacific): a mantle hot line. J. Geophys. Res., 82:2457-2475.

Cheminee, L.L., Hekinian, R., Talandier, J., Albarede, F., Devey, C.W., Francheteau, J., and Lancelot, Y., 1989. Geology of an active hotspot: Teahitaia-Mehetia region in the south-central Pacific. Mar. Geophys. Res., 11:27-50.

Clague, D.A., and Dalrymple, G.B., 1987. The Hawaiian-Emperor volcanic chain. Part I. Geologic evolution. In Decker, R.W., Wright, T.L., and Stauffer, P.H. (Eds.), Volcanism in Hawaii. Geol. Surv. Prof. Pap. U.S., 1350:5-54.

Clague, D.A., and Jarrard, R.D., 1973. Tertiary plate motion deduced from the Hawaiian-Emperor seamount chain. Geol. Soc. Am. Bull., 84:1135-1154.

Dalrymple, G.B., Jarrard, R.D., and Clague, D.A., 1975. K-Ar ages of some volcanic rocks from the Cook and Austral islands. Geol. Soc. Am. Bull., 86:1463-1467.

Davis, A.S., Pringle, M.S., Pickthorn, L.B.G., Clague, D.A., and Schwab, W.C., 1989. Petrology and age of alkalic lava from the Ratak Chain of the Marshall Islands. J. Geophys. Res., 94:5757-5774.

Detrick, R.S., von Herzen, R.P., Parsons, B., Sandwell, D., and Dougherty, M., 1986. Heat flow observation on the Bermuda Rise and thermal models of mid-plate swells. J. Geophys. Res., 97:3701-3723.

Duncan, R.A., 1981. Hotspots in the southern oceans-an absolute frame of reference for motion of the Gondwana continents. Tectonophysics, $74: 29-42$.

Duncan, R.A., and Clague, D.A., 1985. Pacific plate motion recorded by linear volcanic chains. In Nairn, A.E.M., Stehli, F.G., and Uyeda, S. (Eds.), The Ocean Basins and Margins (Vol. 7A): The Pacific Ocean: New York (Plenum), 89-121.

Duncan, R.A., and McDougall, I., 1976. Linear volcanism in French Polynesia. J. Volcanol. Geotherm. Res., 1:197-227.

Duncan, R.A., and Richards, M.A., 1991. Hotspots, mantle plumes, flood basalts, and true polar wander. Rev. Geophys., 29:31-50.

Engebretson, D.C., Cox, A., and Gordon, R.G., 1985. Relative motions between oceanic and continental plates in the Pacific basin. Spec. Pap.Geol. Soc. Am., 206:1-59.

Epp, D., 1978. Age and tectonic relationships among volcanic chains on the Pacific plate [Ph.D. dissert.]. Univ. of Hawaii, Honolulu.

Fleitout, L., and Moriceau, C., 1992. Short-wavelength geoid, bathymetry and the convective pattern beneath the Pacific Ocean. Geophys. J. Int., 110:6-28.

Gordon, R.G., and Cape, C., 1981. Cenozoic latitudinal shift of the Hawaiian hotspot and its implications for true polar wander. Earth Planet. Sci. Lett., $55: 37-47$

Harland, W.B., Armstrong, R.L., Cox, A.V., Craig, L.E., Smith, A.G., and Smith, D.G., 1990. A Geologic Time Scale 1989: Cambridge (Cambridge Univ. Press).

Hein, J.R., Kang, J.K., et al., 1990. Geological, geochemical, geophysical, and oceanographic data and interpretations of seamounts and C-rich ferromanganese crusts from the Marshall Islands, KORDI-USGS R.V. Faranella Cruise F10-89-CP. Open-File Rep.-U.S. Geol. Surv., 90-407, 1-246.

Henderson, L.J., 1985. Motion of the Pacific Plate relative to the hotspots since the Jurassic and model of oceanic plateaus of the Farallon Plate [Ph.D. dissert.]. Northwestern Univ., Evanston, IL.

Henderson, L.J., and Gordon, R.G., 1981. Oceanic plateaus and the motion of the Pacific Plate with respect to the hotspots. Eos, 62:1028.

Jarrard, R.D., and Clague, D.A., 1977. Implications of Pacific island and seamount ages for the origin of volcanic chains. Rev. Geophys. Space Phys., 15:57-76.

Jarrard, R.D. and Turner, D.L., 1979. Comments on "Lithospheric flexure and uplifted atolls" by M. McNutt and H.W. Menard. J. Geophys. Res., 84:5691-5697.

Krummenacher, D., and Noetzlin, J., 1966. Ages isotopiques K/A de roches prevelees dans les possessions Fracaises du Pacifique. Bull. Soc. Geol. Fr., 7:173-175.

\footnotetext{
- Abbreviations for names of organizations and publication titles in ODP reference lists follow the style given in Chemical Abstracts Service Source Index (published by American Chemical Society).
} 
Larson, R.L., Moberly, R., et al., 1975. Init. Repts. DSDP, 32: Washington (U.S. Govt. Printing Office).

Larson, R.L., Schlanger, S.O., et al., 1981. Init. Repts. DSDP, 61: Washington (U.S. Govt. Printing Office).

Lincoln, J.M., 1990. Regional tectonic history and Cenozoic sea levels deduced from drowned carbonate banks and atoll stratigraphy in the Marshall Islands, west central Pacific Ocean [Ph.D. dissert]. Northwestern Univ., Evanston, IL.

Lincoln, J.M., Pringle, M.S., and Premoli-Silva, I., 1993. Early and Late Cretaceous volcanism and reef-building in the Marshall Islands. In Pringle, M.S., Sager, W.W., Sliter, W.V., and Stein, S. (Eds.), The Mesozoic Pacific: Geology, Tectonics, and Volcanism. Geophys. Monogr., Am. Geophys. Union, 77:279-305.

Lonsdale, P., 1988. Geography and history of the Louisville hotspot chain in the Southwest Pacific. J. Geophys. Res., 93:3078-3104.

Matsuda, J.I., Notsu, K., Okano, J., Yaskawa, K., and Chungue, L., 1984. Geochemical implications from $\mathrm{Sr}$ isotopes and $\mathrm{K}$-Ar age determinations for the Cook-Austral Islands chain. Tectonophysics, 104:145-154.

McNutt, M.K., and Fischer, K.M., 1987. The South Pacific superswell. In Keating, B.H., Fryer, P., Batiza, R., and Boehlert, G.W. (Eds.), Seamounts, Islands, and Atolls. Geophys. Monogr., Am. Geophys. Union, 43:25-34.

McNutt, M.K., and Menard, H.W., 1978. Lithospheric flexure and uplifted atolls. J. Geophys. Res., 83:1206-1212.

Menard, H.W., 1964. Marine Geology of the Pacific: New York (McGrawHill).

Minster, J.B., and Jordan, T.H., 1978. Present-day plate motions. J. Geophys. Res., 83:5331-5354.

Moberly, R., and Jenkyns, H.C., 1981. Cretaceous volcanogenic sediments of the Nauru Basin, Deep Sea Drilling Project Leg 61. In Larson, R.L., Schlanger, S.O., et al., Init. Repts. DSDP, 61: Washington (U.S. Govt. Printing Office), 533-548.

Moberly, R., Schlanger, S.O., et al., 1986. Init. Repts. DSDP, 89: Washington (U.S. Govt. Printing Office).

Molnar, P., and Stock, J., 1987. Relative motions of hot spots in the Pacific, Atlantic and Indian oceans since late Cretaceous time. Nature, 327:587591 .

Morgan, W.J., 1972. Plate motions and deep mantle convection. Mem.-Geol. Soc. Am., 132:7-22.

1981. Hotspot tracks and the opening of the Atlantic and Indian Oceans. In Emiliani, C. (Ed.), The Sea (Vol. 7): New York (Wiley), 443-487.

Morgan, W.J., 1983. Hotspot tracks and the early rifting of the Atlantic. Tectonophysics, 94:123-139.

Premoli Silva, I., Haggerty, J., Rack, F., et al., 1993. Proc. ODP, Init. Repts. 144: College Station, TX (Ocean Drilling Program).

Pringle, M.S., 1992. Geochronology and petrology of the Musicians Seamounts: the search for hotspot volcanism in the Cretaceous Pacific. [Ph.D. thesis]. Univ, of Hawaii at Manoa, Honolulu.
Pringle, M.S., and Staudigel, H., 1992. Age and distribution of Cretaceous Pacific seamount volcanism. Eos, 73:586.

Sager, W., and Bleil, U., 1987. Latitudinal shift of Pacific hotspots during the late Cretaceous and early Tertiary. Nature, 326:488-490.

Schlanger, S.O., Jackson, E.D., et al., 1976. Init. Repts. DSDP, 33: Washington (U.S. Govt. Printing Office).

Schlanger, S.O., and Premoli Silva, I., 1981. Tectonic, volcanic, and paleogeographic implications of redeposited reef faunas of Late Cretaceous and Tertiary age from the Nauru Basin and the Line Islands. In Larson, R.L., Schlanger, S.O., et al., Init. Repts. DSDP, 61: Washington (U.S. Govt. Printing Office), 817-827.

Sleep, N.H., 1990. Hotspots and mantle plumes: some phenomenology. $J$. Geophys. Res., 95:6715-6736.

Smith, W.H.F., Staudigel, H., Watts, A.B., and Pringle, M.S., 1989. The Magellan Seamounts: Early Cretaceous record of the South Pacific isotopic and thermal anomaly. J. Geophys. Res., 94:10501-10523.

Staudigel, H., Park, K.-H., Pringle, M.S., Rubenstone, J.L., Smith, W.H.F., and Zindler, A., 1991. The longevity of the South Pacific isotopic and thermal anomaly. Earth Planet. Sci. Lett., 102:24-44.

Stoffers, P., Botz, R., Cheminee, R.-L., Devey, C.W., Froger, V., Glasby, G.P., Hartmann, M., Hekinian, R., Kogler, F., Laschek, D., Larque, P., Michaelis, W., Muhe, R.K., Puteanus, D., and Richnow, H.H., 1989. Geology of Macdonald Seamount region, Austral Islands: recent hotspot volcanism in the South Pacific. Mar. Geophys. Res., 11:101-112.

Turner, D.L., and Jarrard, R.D., 1982. K-Ar dating of the Cook-Austral island chain: a test of the hotspot hypothesis. J. Volcanol. Geotherm. Res., 12:187-220.

Turner, D.L., Jarrard, R.D., and Forbes, R.B., 1980. Geochronology and origin of the Pratt-Welker Seamount Chain, Gulf of Alaska: a new pole of rotation for the Pacific Plate. J. Geophys. Res., 85:6547-6556.

Winterer, E.L., Ewing, J.I., et al., 1973. Init. Repts. DSDP, 17: Washington (U.S. Govt. Printing Office).

Winterer, E.L., Natland, J.H., van Waasbergen, R.J., Duncan, R.A., McNutt, M.K., Wolfe, C.J., Premoli Silva, I., Sager, W.W., and Sliter, W.V., 1993. Cretaceous guyots in the Northwest Pacific: an overview of their geology and geophysics. In Pringle, M.S., Sager, W.W., Sliter, W.V., and Stein, S. (Eds.), The Mesozoic Pacific: Geology, Tectonics, and Volcanism. Geophys. Monogr., Am. Geophys. Union, 77:307-334.

Yan, C.Y., and Kroenke, L.W., 1993. A plate tectonic reconstruction of the southwest Pacific, 0-100 Ma. In Berger, W.H., Kroenke, L.W., Mayer, L.A., et al., Proc. ODP, Sci. Results, 130: College Station, TX (Ocean Drilling Program), 697-709.

\section{Date of initial receipt: 7 February 1994 \\ Date of acceptance: 15 August 1994 \\ Ms 144SR-018}

